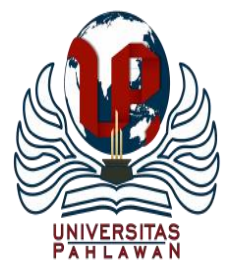

Edukatif : Jurnal Ilmu Pendidikan Volume 3 Nomor 3 Tahun 2021 Halm 1000 - 1009

EDUKATIF: JURNAL ILMU PENDIDIKAN

Research \& Learning in Education

https://edukatif.org/index.php/edukatif/index

\title{
Efektivitas Penggunaan Google Classroom dan Motivasi Belajar Terhadap Hasil Belajar Peserta Didik Mata Pelajaran Ekonomi
}

\author{
Vivi Andyni Destyana ${ }^{1 凶}$, Jun Surjanti \\ Universitas Negeri Surabaya, Indonesia ${ }^{1,2}$ \\ E-mail : vivi.17080554001@ mhs.unesa.ac.id ${ }^{1}$, junsurjanti@ unesa.ac.id ${ }^{2}$
}

\begin{abstract}
Abstrak
Penelitian ini bertujuan untuk mengetahui efektifitas penggunaan google classroom serta untuk mengetahui pengaruh antara efektivitas penggunaan google classroom dan motivasi belajar terhadap hasil belajar peserta didik pada mata pelajaran ekonomi materi indeks harga dan inflasi kelas XI IPS SMAN 1 Puri Mojokerto. Populasi yang digunakan dalam penelitian ini adalah kelas XI IPS SMAN 1 Puri Mojokerto yakni sebanyak 119 peserta didik. Sampel yang digunakan sebanyak 92 dengan menggunakan teknik proporsional random sampling dimana jumlah sampel akan tersebar secara proporsional di masing-masing kelas. Teknik pengumpulan data yang digunakan adalah data primer dan data sekunder. Teknik analisis data yang digunakan dalam penelitian ini adalah analisis deskriptif dan regresi linier berganda dengan bantuan program SPSS versi 26. Berdasarkan hasil analisis data dapat dikatakan bahwa penggunaan google classroom dapat digunakan secara efektif dalam kegiatan belajar mengajar dengan presentase 76,42\%. Kemudian efektifitas google classroom dan motivasi belajar mempengaruhi hasil belajar secara positif dan signifikan.
\end{abstract}

Kata Kunci: efektifitas penggunaan google classroom, motivasi belajar, hasil belajar.

\begin{abstract}
This research aims to determine the effectiveness of the use of google classrooms and to determine the effect of google classrooms and learning motivation on student learning outcomes in economics subjects, price index material, and inflation class XI IPS SMAN 1 Puri Mojokerto. The population used in this study was 119 students of class XI IPS at SMAN 1 Puri Mojokerto. The sample used is 92 by using the proportional random sampling technique where the number of samples will be distributed proportionally in each class. Data collection techniques used are primary data and secondary data. The data analysis technique used in this research is descriptive analysis and multiple linear regression with the help of the SPSS version 26 program. Based on the results of data analysis, it can be said that the use of google classroom can be used effectively in teaching and learning activities with a percentage of $76.42 \%$. Then the effectiveness of google classroom and learning motivation will affect learning outcomes positively and significantly.
\end{abstract}

Keywords: the effectiveness of using google classroom, learning motivation, learning outcomes.

Copyright (c) 2021 Vivi Andyni Destyana, Jun Surjanti

$\triangle$ Corresponding author

Email : vivi.17080554001@mhs.unesa.ac.id

DOI : https://doi.org/10.31004/edukatif.v3i3.507

ISSN 2656-8063 (Media Cetak)

ISSN 2656-8071 (Media Online)

Edukatif : Jurnal Ilmu Pendidikan Vol 3 No 3 Tahun 2021 p-ISSN 2656-8063 e-ISSN 2656-8071 
1001 Efektivitas Penggunaan Google Classroom dan Motivasi Belajar Terhadap Hasil Belajar Peserta Didik Mata Pelajaran Ekonomi - Vivi Andyni Destyana, Jun Surjanti

DOI: https://doi.org/10.31004/edukatif.v3i3.507

\section{PENDAHULUAN}

Dunia pendidikan pada saat ini terutama pada proses pembelajaran sangat terkena dampak dari kemajuan teknologi komunikasi dan informasi, sehingga pendidikan pada abad 21 pembelajaran harus menekankan pada pemanfaatan teknologi. Pendidikan pada abad 21 memberikan kemudahan belajar pada peserta didik yang dapat dilakukan dengan lebih mudah, cepat serta lebih murah (Mayasari et al., 2016). Pembelajaran yang diharapkan pada abad 21 akan menekankan pada kemampuan peserta didik dalam mengakses sebuah informasi, menganalisis masalah, kemampuan berpikir kritis serta pemecahan sebuah masalah yang dihadapi (Zubaidah, 2016). Selain itu pembelajaran abad 21 juga menerapkan kecakapan informasi, media dan teknologi (Effendi \& Wahidy, 2019). Dalam penerapan pembelajaran sesuai dengan abad 21, motivasi belajar perlu dimiliki oleh setiap peserta didik agar mampu mengikuti perkembangan teknologi sehingga dapat meningkatkan hasil belajarnya.

Motivasi merupakan suatu dorongan atau kekuatan baik yang ada diluar maupun dalam diri sendiri sehingga dapat mendorong keinginan untuk belajar (Nirfayanti \& Nurbaeti, 2019). Keberhasilan belajar dari peserta didik merupakan pengaruh salah satu faktor dari motivasi (Trisnaningsih et al., 2016). Motivasi belajar yang tinggi diharapkan akan mendapatkan hasil belajar yang baik. Pentingnya motivasi belajar dibentuk untuk mengubah pembelajaran ke arah yang lebih positif. Peserta didik dapat lebih banyak serta lebih cepat dalam melakukan kegiatan belajar mengajar apabila mereka mempunyai motivasi yang baik dalam dirinya, sedangkan peserta didik yang kurang termotivasi mereka cenderung kurang semangat dalam belajar. Hasil belajar peserta didik akan lebih baik jika mereka memiliki motivasi yang tinggi (Alhadi et al., 2017). Namun tidak menutup kemungkinan bahwa motivasi dan hasil belajar akan rendah apabila pada saat kegiatan belajar mengajar guru tidak dapat menyesuaikan kondisi dan suasana dalam kelas. Dalam hal ini motivasi dan hasil belajar tidak lepas dari peran guru dalam memberikan pembelajaran serta bimbingan kepada peserta didiknya. Oleh karena itu penggunaan penggunaan yang menarik serta sesuai dengan kebutuhan dari peserta didiknya perlu dilakukan. Dengan adanya era teknologi yang semakin berkembang ini guru dapat melakukan kegiatan belajar mengajar dengan memanfaatkan teknologi (Putri \& Dewi, 2019).

SMAN 1 Puri Mojokerto merupakan salah satu sekolah yang telah menggunakan teknologi dalam proses pembelajarannya. Penggunaan teknologi pada pembelajaran tersebut dikarenakan adanya pandemic covid 19 yang membuat sekolah harus menggunakan sistem pembelajaran secara daring. Pembelajaran secara daring diterapkan oleh guru pada seluruh mata pelajaran ekonomi. Berdasarkan observasi yang dilakukan peneliti, guru mengatakan sebelumnya sekolah tidak pernah menggunakan sistem pembelajaran secara daring. Pembelajaran dengan sistem daring dimulai sejak adanya pandemic covid 19 pada tahun ajaran 2020/2021. Pembelajaran secara daring ini belum terbiasa dilakukan oleh peserta didik sehingga menyebabkan hasil belajar rendah. Berdasarkan hasil wawancara dengan guru ekonomi , menjelaskan bahwa hasil belajar peserta didik rendah dalam pembelajaran dikarenakan media yang digunakan saat proses belajar mengajar adalah media tatap muka secara jarak jauh. Jadi tidak semua peserta didik mempunyai kuota dan koneksi internet yang cukup. Hampir semua peserta didik merasa kesulitan pada saat menggunakan media tersebut. Selain itu, selama kegiatan belajar mengajar hampir semua peserta didik tidak menanggapi guru. Sehingga guru juga kesulitan dalam mengontrol peserta didik karena tidak bisa melakukan pengawasan secara langsung. Hal tersebut menyebabkan hasil belajar pada peserta didik mengalami penurunan. Pada materi indeks harga dan inflasi peserta didik memperoleh nilai paling rendah daripada materi lain. Hasil belajar peserta didik sebesar $60 \%$ masih berada dibawah KKM. Berdasarkan pernyataan tersebut, guru membutuhkan sebuah aplikasi yang mudah untuk digunakan sehingga pada saat guru menyajikan materi secara online maka akan lebih mudah dipahami oleh peserta didik.

Selama proses pembelajaran secara online google classroom merupakan sebuah aplikasi yang mudah digunakan. Google classroom sendiri merupakan LMS (Learning Management System) yaitu sebuah aplikasi 
1002 Efektivitas Penggunaan Google Classroom dan Motivasi Belajar Terhadap Hasil Belajar Peserta Didik Mata Pelajaran Ekonomi - Vivi Andyni Destyana, Jun Surjanti

DOI: https://doi.org/10.31004/edukatif.v3i3.507

perangkat lunak yang bisa digunakan untuk mendukung proses pembelajaran online (Shaharanee et al., 2016). Penggunaan google classroom dapat memudahkan guru maupun peserta didik dalam belajar (Sukmawati, 2020). Google classroom dapat digunakan untuk membuat ruang kelas yang dapat mempermudah guru dalam memberikan respon atau umpan balik secara efisien, mengatur dan membuat sebuah tugas dengan lebih cepat, serta dapat melakukan komunikasi secara jarak jauh menjadi lebih mudah. Selain itu juga dapat digunakan untuk merekam data peserta didik sehingga dapat memperoleh sebuah laporan sehingga sangat berguna untuk memaksimalkan efektivitas dari sebuah pembelajaran (Harefa \& Sumiyati, 2020). Hal ini dibuktikan oleh penelitian (Abid Azhar \& Iqbal, 2018) yang menyatakan bahwa pembelajaran dapat efektif apabila menggunakan google classroom, karena guru dapat mengunggah tugas, melakukan manajemen kelas, dan komunikasi dengan peserta didik. Google classroom juga dapat digunakan untuk penyimpanan data pada google drive serta dapat menampung segala jenis file yang dapat diakses menggunakan smartphone, sehingga dapat membuat peserta didik termotivasi dan berpartisipasi aktif pada saat melakukan pembelajaran secara daring (Suhada et al., 2020).

Motivasi adalah suatu daya atau kekuatan yang timbul dari dalam diri peserta didik untuk memberikan kesiapan agar tujuan yang telah ditetapkan dapat tercapai. Keberadaan dari motivasi merupakan suatu hal yang diperlukan dalam kegiatan pembelajaran karena dapat menimbulkan perasaan semangat dan senang dalam belajar (Gianistika, 2021). Motivasi dalam belajar merupakaan salah satu hal yang sangat penting untuk menunjang keberhasilan dalam belajar. Peserta didik yag termotivasi maka akan mempunyai semangat dalam belajar, sehingga pada saat menghadapi kesulitan peserta didik dapat melewatinya serta endapatkan hasil belajar yang baik (Pratama et al., 2019). Baik guru maupun peserta didik harus memiliki motivasi agar tujuan pembelajaran yang diinginkan dapat tercapai. Apabila peserta didik termotivasi maka akan mempengaruhi hasil belajar, sehingga hasil belajar akan tinggi jika peserta didik termotivasi. Hal ini dibuktikan oleh penelitian (Stevani, 2016) bahwa motivasi belajar mempengaruhi peningkatan hasil belajar.

Hasil belajar adalah suatu perubahan tingkah laku peserta didik yang dapat dilihat dan diukur dalam bentuk pengetahuan, sikap dan keterampilan yang dimiliki Hamalik (dalam Sutrisno, 2020). Hasil belajar merupakan hal yang penting dalam proses pembelajaran karena hal ini merupakan indikator yang dapat dijadikan acuan untuk mengetahui kemajuan belajar siswa, menjadi umpan balik bagi perbaikan proses pembelajaran agar mencapai tujuan pembelajaran yang telah ditentukan (Sulisworo et al., 2017). Hasil belajar dapat digunakan sebagai ukuran dalam menentukan kemampuan atau kompetensi yang dimiliki oleh peserta didik setelah memdapatkan pengalaman pembelajaran.

Adapun penelitian terdahulu yang telah meneliti tentang google classroom, proses pembelajaran dilakukan secara langsung dikarenakan penelitian tersebut adalah penerapan. Namun pada kondisi pandemi saat ini seluruh pembelajaran diharuskan secara online, jadi guru diarahkan untuk menggunakan aplikasi belajar google classroom pada saat pembelajaran berlangsung. Sehingga keterbatasan penelitian ini adalah hanya menganalisis keefektifan penggunaan google classroom dalam proses belajar mengajar secara online. Penelitian yang dilakukan oleh (Tanami Sukraini et al., 2020) memperoleh hasil bahwa penerapan google classroom berpengaruh signifikan dan mampu meningkatkan hasil belajar. Dengan demikian penelitian ini dilakukan untuk menganalisa apakah penggunaan google classroom mampu berpengaruh secara signifikan pada hasil belajar seperti penelitian sebelumnya. Mengingat pada kondisi pandemi saat ini pembelajaran harus tetap dilaksanakan sesuai dengan tujuan pembelajaran yang telah ditentukan.

Berdasarkan pada uraian, tujuan dari penelitian ini adalah untuk mengetahui keefektifan penggunaan google classroom. Kemudian untuk mengetahui pengaruh efektifitas penggunaan google classroom dan motivasi belajar terhadap hasil belajar peserta didik pada mata pelajaran ekonomi materi indeks harga dan inflasi kelas XI IPS di SMAN 1 Puri Mojokerto. Sehingga penelitian ini dilakukan untuk mengetahui pengaruh variabel secara parsial dan simultan. 
1003 Efektivitas Penggunaan Google Classroom dan Motivasi Belajar Terhadap Hasil Belajar Peserta Didik Mata Pelajaran Ekonomi - Vivi Andyni Destyana, Jun Surjanti

DOI: https://doi.org/10.31004/edukatif.v3i3.507

\section{METODE}

Penelitian ini merupakan penelitian korelasional dengan pendekatan kuantitatif. Penelitian kuantitaif adalah penelitian pengambilan data berupa angka yang dianalisis dalam bentuk statistic secara kuantitatif. Jenis penelitian korelasional digunakan untuk mencari hubungan atau pengaruh yang terdiri dari dua variabel atau lebih, yaitu hubungan antara efektivitas Google classroom (X1) dan motivasi belajar (X2) (variabel bebas) dengan hasil belajar (Y) (variabel terikat). Populasi yang digunakan adalah peserta didik kelas XI IPS yang terdiri dari XI IPS 1, 2,3, dan 4 sebanyak 119 peserta didik. Sampel yang digunakan dari jumlah populasi sebanyak 92 peserta didik. Untuk memperoleh sampelnya menggunakan teknik sampel proporsional random sampling dimana sampel akan tersebar secara proporsional pada setiap kelas. Pada kelas XI IPS 1 jumlah sampel sebanyak 23, pada kelas XI IPS 2 sebanyak 23, pada kelas XI IPS 3 sebanyak 23, dan pada kelas XI IPS 4 juga 23 peserta didik.

Teknik pengumpulan data yang digunakan pada penelitian ini adalah data primer dan sekunder. Data primer yakni, 1) Observasi, dengan melakukan pengamatan yang meliputi kegiatan pemantauan serta perhatian terhadap suatu objek yang akan diteliti. 2) Wawancara, yakni penggunaan teknik pengumpulan data ini untuk memperoleh permasalahan yang terjadi dilapangan berkaitan dengan kegiatan belajar mengajar. 3) Kuisioner, merupakan pengumpulan data dengan penyebaran kuisioner pada responden sehingga responden dapat memberikan jawaban. Sedangkan data sekunder adalah: 1) Dokumen, diperlukan untuk menunjang penelitian yang berkaitan dengan variabel yang akan diteliti. 2) Perpustakaan, dapat menambah referensi penulis melalui literature-literatur serta buku-buku yang ada diperpustakaan. 3) Jurnal, dari penelitian yang sudah dilakukan sebelumnya peneliti dapat menambahkan refensi pada penelitian yang berkaitan dengan variabel yang diteliti.

Teknik analisis data dilakukan menggunakan analisis deskriptif, yakni data yang telah diperoleh peneliti yang sudah ditentukan akan dideskripsikan melalui penyajian data menggunakan tabel. Indikator dalam mengukur keefektifan google classroom menurut (Suhada et al. 2020) antara lain, kemudahan dalam mengakses aplikasi google classroom, pemahaman materi pembelajaran dengan menggunakan google classroom, kemudahan penggunaan aplikasi google classroom dalam pembelajaran daring. Kemudian indikator yang digunakan dalam mengukur variabel motivasi belajar dalam penelitian ini menurut (Aritonang 2013) adalah ketekunan dalam belajar, ulet dalam menghadapi kesulitan, minat dan ketajaman perhatian dalam belajar, berprestasi dalam belajar, mandiri dalam belajar. Untuk hasil belajar dapat dilihat dari nilai PTS (Penilaian Tengan Semester) genap tahun 2020/2021. Berdasarkan indikator tersebut maka keefektifan google classroom akan dianalisis secara deskriptif yang dilihat dari besarnya nilai rata-rata dari hasil penyebaran kuisioner dengan klasifikasi sebagai berikut :

\section{Tabel 1}

Kriteria Jawaban Responden

\begin{tabular}{|c|c|c|}
\hline No. & Presentasi Pencapaian & Kategori \\
\hline 1. & $81-100 \%$ & Sangat baik \\
2. & $61-80 \%$ & Baik \\
3. & $41-60 \%$ & Cukup Baik \\
4. & $21-40 \%$ & Kurang Baik \\
5. & $0-21 \%$ & Tidak Baik \\
\hline
\end{tabular}

Sumber : (Arikunto, 2010)

Kemudian juga menggunakan analisis regresi linier berganda untuk mengetahui pengaruh antara efektivitas penggunaan Google classroom (X1) dan motivasi belajar (X2) terhadap hasil belajar (Y). Sebelum dilakukan uji regresi linier berganda akan dilakukan uji validitas dan realibilitas terlebih dahulu untuk menetukan valid tidaknya suatu instrument. Penggunaan skala ordinal dalam penelitian perlu diubah terlebih dahulu ke data interval. Hal tersebut bertujuan untuk memenuhi sebagian dari syarat analisis, dimana data 
1004 Efektivitas Penggunaan Google Classroom dan Motivasi Belajar Terhadap Hasil Belajar Peserta Didik Mata Pelajaran Ekonomi - Vivi Andyni Destyana, Jun Surjanti

DOI: https://doi.org/10.31004/edukatif.v3i3.507

setidaknya dapat berskala interval. Selain itu tujuan dari perubahan data ordinal ke interval adalah data dapat berdistribusi normal dan selanjutnya dapat dilakukan uji asumsi klasik, yakni uji normalitas, uji linieritas dan uji heteroskedastisitas (Ridwan and Kuncoro 2008). Perubahan data ordinal ke interval dilakukan dengan menggunaan Method of Successive Interval (MSI) pada Microsoft Exel. Setelah itu peneliti dapat melakukan analisis regresi berganda. Data yang digunakan dalam uji regresi linier berganda merupakan data yang diperoleh dari hasil penyebaran kuisioner dengan menggunakan skala Likert dimana jawaban diberi skor antara 1 sampai 5 .

\section{HASIL DAN PEMBAHASAN}

\section{Analisis Efektivitas Penggunaan Google classroom}

Efektivitas penggunaan google classroom ditinjau dari respon peserta didik melalui penyebaran kuisioner yang dirata-rata menggunakan rumus presentase sebagai berikut :

$$
x=\frac{\text { Nilai Yang Diperoleh }}{\text { Jumlah Item } x \text { Skor Ideal } x \text { Jumlah responden }} \times 100
$$

Berdasarkan rumus tersebut maka diperoleh hasil dibawah ini:

Tabel 2

Presentase Efektivitas Penggunaan Google classroom

\begin{tabular}{|c|c|c|c|c|}
\hline \multirow[t]{2}{*}{ No. } & \multirow[t]{2}{*}{ Indikator } & $\begin{array}{c}\text { Rata- } \\
\text { rata }\end{array}$ & $\begin{array}{l}\text { Presentasi } \\
\text { Pencapaian }\end{array}$ & \multirow[t]{2}{*}{ Kategori Jawaban } \\
\hline & & Mean & $\%$ & \\
\hline 1 & $\begin{array}{l}\text { Kemudahan dalam mengakses aplikasi } \\
\text { google classroom }\end{array}$ & 4.07 & 81.3 & Sangat Baik \\
\hline 2 & $\begin{array}{l}\text { Pemahaman materi pembelajaran dengan } \\
\text { menggunakan google classroom }\end{array}$ & 3.57 & 71.3 & Baik \\
\hline 3 & $\begin{array}{l}\text { Kemudanan penggunaan aplikasi google } \\
\text { classroom }\end{array}$ & 3.83 & 76.65 & Baik \\
\hline \multicolumn{2}{|r|}{ Rata-rata Variabel } & 3.82 & 76.42 & Baik \\
\hline
\end{tabular}

Hasil tabel 2 diketahui bahwa efektivitas penggunaan google classroom dapat dilihat dari penggunaannya dan diukur dari tiga indikator, yaitu Kemudahan dalam mengakses aplikasi google classroom, Pemahaman materi pembelajaran dengan menggunakan google classroom, dan Kemudahan penggunaan aplikasi google classroom. Berdasarkan dari hasil penelitian yang dilakukan besarnya nilai rata-rata dari hasil penyebaran kuisioner adalah sebesar 3,82 dengan presentasi pencapaian sebesar 76,42\% yang masuk pada kategori jawaban Baik. Hal tersebut menunjukkan bahwa google classroom efektif untuk digunakan pada pembelajaran. Peserta didik dapat lebih mudah serta lebih cepat dalam berinteraksi dengan guru ataupun teman lainnya pada saat proses belajar mengajar, sehingga kegiatan pembelajaran dapat berjalan dengan lancar. Hal tersebut sejalan dengan penelitian yang sudah dilakukan oleh (Nirfayanti \& Nurbaeti, 2019) yang mengatakan media google classroom dirancang agar mempermudah peserta didik dan guru dalam berinteraksi.

Indikator pertama, yaitu kemudahan dalam mengakses aplikasi google classroom. Berdasarkan dari hasil penelitian yang dilakukan besarnya nilai rata-rata dari hasil penyebaran kuisioner adalah sebesar 4,07 dan presentasi pencapaian sebesar $81,3 \%$ yang masuk pada kategori jawaban sangat baik. Hal ini menunjukkan bahwa aplikasi google classroom sangat mudah digunakan dalam pembelajaran. Penggunaan media google classroom yang cukup mudah membuat semua peserta didik dapat mengakses dengan cepat tanpa harus menghabiskan kuota, karena media ini tidak memakan kuota yang besar dalam penggunaannya. Kemudian dalam mengakses penggunaan ini tidak terbatas oleh waktu, jadi peserta didik dapat 
1005 Efektivitas Penggunaan Google Classroom dan Motivasi Belajar Terhadap Hasil Belajar Peserta Didik Mata Pelajaran Ekonomi - Vivi Andyni Destyana, Jun Surjanti

DOI: https://doi.org/10.31004/edukatif.v3i3.507

menggunakannya kapan dan dimana saja. Sehingga pembelajaran dapat dilakukan secara optimal dan dapat mempermudah dalam merealisasikan tujuan pembelajaran (Gunawan \& Sunarman, 2017).

Indikator kedua, yaitu pemahaman materi pembelajaran dengan google classroom. Berdasarkan dari hasil penelitian yang dilakukan besarnya nilai rata-rata dari hasil penyebaran kuisioner adalah sebesar 3,57 dan presentasi pencapaian sebesar 71,3 yang masuk pada kategori jawaban baik. Dengan demikian penggunaan google classroom mempermudah peserta didik memahami materi yang disajikan. Penggunaan media google classroom tanpa adanya batasan waktu membuat peserta didik bisa kapan saja dalam memahami materi. Apabila peserta didik belum terlalu memahami pada saat kegiatan belajar mengajar dilakukan, maka mereka bisa mempelajarinya lagi pada sore atau malam hari. Hal ini sesuai dengan penelitian (Heggart \& Yoo, 2018) yang menyatakan bahwa proses belajar mengajar sangat tepat dilakukan dengan menggunakan google classroom sehingga peserta didik mudah dalam memahami materi.

Indikator ketiga, yaitu kemudahan penggunaan aplikasi google classroom. Berdasarkan dari hasil penelitian yang dilakukan besarnya nilai rata-rata dari hasil penyebaran kuisioner adalah sebesar 3,66 dan presentasi pencapaian sebesar 73,19 dengan kategori jawaban adalah baik. Dengan demikian aplikasi google classroom efektif digunakan pada saat pembelajaran. Sejalan dengan penelitian (Sabran \& Sabara, 2019) yang menjelaskan bahwa pelaksanaan pembelajaran dengan menggunakan google classroom efektif untuk digunakan. Sehingga layak untuk digunakan pada saat pembelajaran daring.

Oleh karena itu dapat ditarik kesimpulan bahwa penggunaan penggunaan google classroom efektif digunakan pada pembelajaran ekonomi di SMAN 1 Puri Mojokerto. Karena pembelajaran saat ini membutuhkan media yang mudah digunakan agar pembelajaran dapat berjalan dengan baik.

\section{Hasil Pengujian Hipotesis Efektivitas Penggunaan Google classroom (X1) Terhadap Hasil Belajar (Y)}

Hasil pengujian hipotesis pertama yakni efektifitas penggunaan google classroom terhadap hasil belajar mata pelajaran ekonomi diperoleh sebagai berikut:

Tabel 3

Uji T X1 Terhadap Y

\begin{tabular}{|c|c|c|c|c|c|c|}
\hline \multicolumn{7}{|c|}{ Coefficients $^{\mathrm{a}}$} \\
\hline \multirow{2}{*}{\multicolumn{2}{|c|}{ Model }} & \multicolumn{2}{|c|}{ Unstandardized Coefficients } & $\begin{array}{l}\text { Standardized } \\
\text { Coefficients }\end{array}$ & \multirow[b]{2}{*}{$\mathrm{t}$} & \multirow[b]{2}{*}{ Sig. } \\
\hline & & $\mathrm{B}$ & Std. Error & Beta & & \\
\hline 1 & (Constant) & 44.645 & 5.711 & & 7.818 & .000 \\
\hline & Google classroom & .072 & .052 & 117 & 2.365 & .026 \\
\hline & Motivasi Belajar & .469 & .069 & .579 & 6.779 & .000 \\
\hline
\end{tabular}

Sumber : Pengolahan Data SPSS V.26

Hasil uji hipotesis petama menunjukkan nilai b1 (nilai koefisien regresi X1) sebesar 0,072, yang artinya variabel efektivitas penggunaan google classroom mempunyai pengaruh yang positif terhadap hasil belajar. Nilai signifikansi yang digunakan adalah 0,05 dan ttabel $=\mathrm{t}(\mathrm{a} / 2: \mathrm{n}-\mathrm{k}-1)=(0,05 / 2: 30-2-1)=0.025: 27=$ 2.025. Berdasarkan uji $\mathrm{t}$ (parsial) dapat diketahui bahwa nilai signifikansi sebesar 0,026 $<0,05$ dan thitung $2.365>$ ttabel 2.025 yang artinya terdapat pengaruh yang signifikan antara efektivitas penggunaan google classroom dengan hasil belajar. Sehingga dapat dikatakan bahwa Ha1 atau hipotesis pertama diterima Dengan demikian dapat disimpulkan bahwa efektifitas penggunaan google classroom (X1) bepengaruh positif dan signifikan terhadap hasil belajar (Y) peserta didik pada materi indeks harga dan inflasi kelas XI IPS SMAN 1 Puri Mojokerto.

Berdasarkan hasil tersebut, dapat dikatakan bahwa penggunaan aplikasi google classroom dalam pembelajaran efektif apabila digunakan. Adanya pengaruh yang terjadi menunjukkan bahwa penggunaan aplikasi ini diminati oleh peserta didik, hal tersebut disebabkan oleh kemudahan interaksi dari guru dengan 
1006 Efektivitas Penggunaan Google Classroom dan Motivasi Belajar Terhadap Hasil Belajar Peserta Didik Mata Pelajaran Ekonomi - Vivi Andyni Destyana, Jun Surjanti

DOI: https://doi.org/10.31004/edukatif.v3i3.507

murid tanpa terbatas ruang dan waktu sehingga peserta didik dapat berulang kali dalam membaca serta memahami materi yang disampaikan. Kemudian peserta didik juga dapat belajar atau mengerjakan tugas kapan saja dan dimana saja. Apabila google classroom digunakan dalam pembelajaran maka peserta didikdapat belajar dengan baik, sehingga akan terjadi peningkatan dalam hasil belajar yang signifikan. Selain itu pembelajaran juga akan berjalan secara optimal yang membuat hasil belajar peserta didik akan meningkat. Hal ini didukung oleh penelitian (Rahmanto \& Bunyamin, 2020) bahwah hasil belajar peserta didik semakin meningkat setiap harinya dengan menggunakan google classroom.

\section{Hasil Pengujian Hipotesis Motivasi Belajar (X2) Terhadap Hasil Belajar (Y)}

Hasil pengujian hipotesis pertama yakni motivasi belajar terhadap hasil belajar mata pelajaran ekonomi diperoleh sebagai berikut:

\section{Tabel 4}

Hasil Uji T X2 Terhadap Y

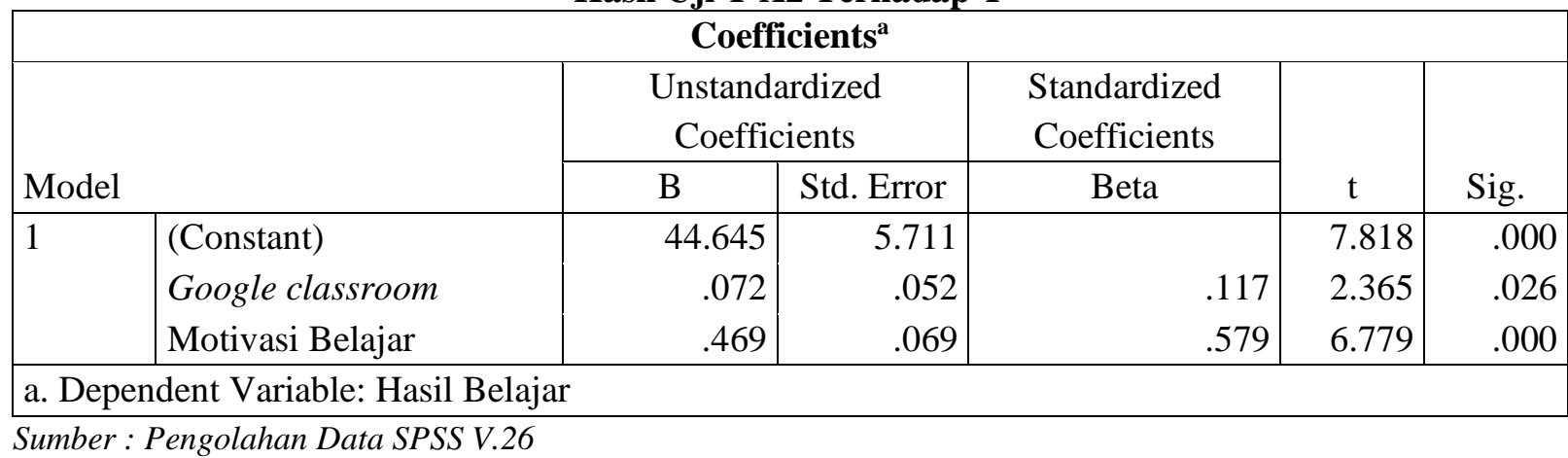

Hasil Uji hipoteis kedua menunjukkan nilai b2 (nilai koefisien regresi X2) sebesar 0,469, artinya motivasi belajar mempengaruhi hasil belajar secara positif. Nilai yang diperoleh dari uji t adalah $0,000<0,05$ kemudian thitung $6.779>$ thabel 2.025 artinya variabel motivasi belajar mempengaruhi hasil belajar secara signifikan. Maka Ha2 atau hipotesis kedua diterima. Sehingga peneliti dapat menyimpulkan bahwa motivasi belajar (X2) dengan hasil belajar (Y) mempunyai pengaruh yang positif dan signifikan pada pelajaran ekonomi kelas XI IPS SMAN 1 Puri Mojokerto.

Berdasarkan hasil tersebut maka dikatakan bahwa pada saat motivasi belajar tinggi maka hasil belajar akan mengalami peningkatan. Motivasi merupakan sebuah keinginan pada diri peserta didik dalam melakukan suatu kegiatan atau yang dimaksud adalah belajar. Peserta didik akan bersungguh-sungguh dan tekun pada saat belajar apabila dirinya mempunyai morivasi yang tinngi agar dapat memperoleh hasil yang maksimal. Hal ini didukung oleh penelitian (Novalinda et al., 2018) bahwa motivasi pada diri peserta didik dapat ditunjukkan dalam minat dan perhatian dalam pelajaran kemudian juga semangat serta tanggungjawab peserta didik dalam menyelesaikan tugasnya. Adanya motivasi yang tinggi pada peserta didik maka mereka akan mudah dalam mencapai tujuan yang diharapkan. Hal tersebut juga didukung oleh penelitian (Stevani, 2016) bahwa motivasi belajar mempengaruhi hasil belajar secara signifikan pada materi pelajaran ekonomi.

\section{Hasil Pengujian Hipotesis Efektivitas Penggunaan Google classroom (X1) dan Motivasi Belajar (X2) Terhadap Hasil Belajar (Y)}

\section{Tabel 5}

Hasil Uji F (Simultan)

\begin{tabular}{|c|c|c|c|c|c|c|}
\hline \multicolumn{7}{|c|}{ ANOVA $^{\mathrm{a}}$} \\
\hline \multicolumn{2}{|c|}{ Model } & Sum of Squares & df & Mean Square & $\mathrm{F}$ & Sig. \\
\hline \multirow[t]{3}{*}{1} & Regression & 1108.515 & 2 & 554.257 & 26.719 & $.000^{\mathrm{b}}$ \\
\hline & Residual & 1846.224 & 89 & 20.744 & & \\
\hline & Total & 2954.739 & 91 & & & \\
\hline
\end{tabular}


1007 Efektivitas Penggunaan Google Classroom dan Motivasi Belajar Terhadap Hasil Belajar Peserta Didik Mata Pelajaran Ekonomi - Vivi Andyni Destyana, Jun Surjanti

DOI: https://doi.org/10.31004/edukatif.v3i3.507

a. Dependent Variable: Hasil Belajar

b. Predictors: (Constant), Motivasi Belajar, Media Google classroom

Sumber : Pengolahan Data SPSS V.26

Tabel 6

Hasil Uji Koefisien Determinasi

\begin{tabular}{|l|c|c|c|r|}
\hline \multicolumn{5}{|c|}{ Model Summary } \\
\hline Model & R & R Square & Adjusted R Square & Std. Error of the Estimate \\
\hline 1 & $.613^{\mathrm{a}}$ & .375 & .361 & 4.55457 \\
\hline \multicolumn{4}{|r|}{ a. Predictors: (Constant), Motivasi Belajar, Media Google classroom } \\
\hline
\end{tabular}

Sumber : Pengolahan Data SPSS V.26

Berdasarkan hasil tabel 5 bahwa nilai signifikansi yang digunakan adalah 0,05 sedangkan nilai ftabel $=$ 3.35.Berdasarkan uji regresi linier berganda atau uji f (simultan) diketahui bahwa nilai (Y) adalah 0,000 < 0,05 sedangkan nilai fhitung $26.719>$ ftabel 3.35. Sehingga dapat dibuktiksn Ha3 atau hipotesis ketiga diterima. Artinya variabel efektifitas google classroom (X1) dan motivasi belajar (X2) scara bersama-sama mempengaruhi hasil belajar (Y) secara signifikan. Berdasarkan uji koefisien determinasi nilai R Square (R2) diperoleh 0,375 atau 37,5\%, artinya pengaruh variabel efektifitas penggunaan google classroom (X1) dan motivasi belajar (X2) terhadap hasil belajar (Y) adalah 37,5\%. Sedangkan sebesar 62,5\% dipengaruhi variabel lainnya yang tidak diteliti oleh peneliti.

Hasil penelitian menunjukkan bahwa efektifitas penggunaan google classroom dan motivasi belajar berpengaruh terhadap hasil belajar. Ketika suatu aplikasi yang diterapkan dalam pembelajaran efektif dan motivasi belajar peserta didik tinggi maka hasil belajar akan semakin baik. Hal ini didukung oleh penelitian (Bintarawati \& Citriadin, 2020) bahwa implementasi kelas virtual dengan menggunakan google classroom mampu meningkatkan hasil belajar dari peserta didik. Kemudian juga didukung penelitian dari (Abdillah, 2017) bahwa penggunaan media pembelajaran dan minat belajar dengan motivasi belajar sebagai variabel intervening mempengaruhi hasil belajar dengan positif dan signifikan.

Dengan demikian dapat diketahui bahwa efektifitas penggunaan dari google classroom dan motivasi belajar peserta didik mampu meningkatkan hasil belajar dari peserta didik. Efektifitas penggunaan google classroom sangat dibutuhkan dalam kegiatan belajar mengajar, karena semakin efektif penggunaan aplikasi belajar maka semakin tinggi minat belajar peserta didik yang dapat meningkatkan hasil belajarnya. Kemudian motivasi yang ada pada diri peserta didik merupakan suatu hal yang sangat penting. Jadi ketika peserta didik memiliki motivasi yang tinggi maka mereka akan bersemangat dalam belajar sehingga hasil belajarnya juga akan mengalami peningkatan. Namun keterbatasan pada penelitian ini adalah peneliti tidap dapat melakukan tatap muka secara langsung apabila pembelajaran dilakukan secara online. Karena aplikasi google classroom tidak dapat digunakan untuk video conference. Tetapi hal tersebut tidak mengurangi kualitas dari penelitian yang sudah dilakukan.

\section{KESIMPULAN}

Kesimpulan yang diperoleh berdasarkan pengujian hipotesis serta analisis data yang sudah dilakukan, yakni : 1) Penggunaan google classroom dalam kegiatan pembelajaran efektif untuk digunakan pada pelajaran ekonomi terutama materi indeks harga dan inflasi. 2) Efektivitas penggunaan google classroom dapat membuat hasil belajar peserta didik meningkat. Hal tersebut dibuktikan melalui hasil uji hipotesis yang diperoleh pengaruh efektivitas penggunaan google classroom terhadap hasil belajar adalah signifikan. 3) Motivasi belajar dapat membuat peerta didik mengalami peningkatanterhadap hasil belajarnya. Hal tersebut dapat dibuktikan dengan hasil uji hipotesis bahwa motivasi belajar mempengaruhi hasil belajar secara signifikan. 4) Efektivitas penggunaan google classroom dan motivasi belajar secara bersama-sama mampu mebuat hasil belajar dari peserta didik mengalami peningkatan. Hasil uji hipotesis menunjukkan bahwa 
1008 Efektivitas Penggunaan Google Classroom dan Motivasi Belajar Terhadap Hasil Belajar Peserta Didik Mata Pelajaran Ekonomi - Vivi Andyni Destyana, Jun Surjanti

DOI: https://doi.org/10.31004/edukatif.v3i3.507

efektivitas penggunaan google classroom dan motivasi belajar berpengaruh terhadap hasil belajar secara signifikan.

\section{DAFTAR PUSTAKA}

Abdillah, A. (2017). Efektivitas Media Pembelajaran Dan Minat Belajar Pengaruhnya Terhadap Hasil Belajar Akuntansi Dengan Motivasi Belajar Sebagai Variabel Intervening Pada Siswa Kelas Xi Smk Negeri Dan Swasta Di Jakarta Timur An. Jurnal Online STKIP PGRI Tulungagung, 1(2). https://doi.org/10.29100/.v1i2.222

Abid Azhar, K., \& Iqbal, N. (2018). Effectiveness of Google Classroom: Teachers' Perceptions. Prizren Social Science Journal, 2(2), 52-66.

Alhadi, S., Nanda, W., \& Saputra, E. (2017). The Relationship between Learning Motivation and Learning Outcome of Junior High School Students in Yogyakarta. Advances in Social Science, Education and Humanities Research (ASSEHR), 66(Yicemap), 138-141.

Arikunto, S. (2010). Prosedur Metedologi Penelitian: Suatu Pendekatan Praktis. Penerbit Rineka Cipta.

Bintarawati, D., \& Citriadin, Y. (2020). Implementasi Kelas Virtual Dengan Google Classroom Untuk Meningkatkan Hasil Belajar Kimia Di Sma Negeri Bekasi. Spin Jurnal Kimia \& Pendidikan Kimia, 2(2), 177-190. https://doi.org/10.20414/spin.v2i2.2573

Effendi, D., \& Wahidy, A. (2019). Pemanfaatan Teknologi dalam Proses Pembelajaran Menuju Pembelajaran Abad 21. Jurnal Online Universitas Pgri Palembang, 2, 125-129. https://jurnal.univpgripalembang.ac.id/index.php/Prosidingpps/article/view/2977/2799

Gianistika, C. (2021). Strategi Pembelajaran Contextual Teaching dan Motivasi Siswa terhadap Hasil Belajar Membaca Nyaring Bahasa Indonesia. EDUKATIF : Jurnal Ilmu Pendidikan, 3(3), 656-671.

Gunawan, F. I., \& Sunarman, S. G. (2017). Pengembangan Kelas Virtual Dengan Google Classroom Dalam Keterampilan Pemecahan Masalah (Problem Solving) Topik Vektor Pada Siswa Smk Untuk Mendukung Pembelajaran. Prosiding Seminar Nasional Etnomatnesia, 340-348.

Harefa, N., \& Sumiyati. (2020). Persepsi Siswa terhadap Google Classroom sebagai LMS pada masa Pandemi Covid-19. Science Education and Application Journal, 2(2), 88. https://doi.org/10.30736/seaj.v2i2.270

Heggart, K. R., \& Yoo, J. (2018). Getting the most from google classroom: A pedagogical framework for tertiary educators. Australian Journal of Teacher Education, 43(3), 140-153. https://doi.org/10.14221/ajte.2018v43n3.9

Mayasari, T., Kadarohman, A., Rusdiana, D., \& Kaniawati, I. (2016). Apakah Model Pembelajaran Problem Based Learning Dan Project Based Learning Mampu Melatihkan Keterampilan Abad 21? Jurnal Pendidikan Fisika Dan Keilmuan (JPFK), 2(1), 48. https://doi.org/10.25273/jpfk.v2i1.24

Nirfayanti, N., \& Nurbaeti, N. (2019). Pengaruh Media Pembelajaran Google Classroom Dalam Pembelajaran Analisis Real Terhadap Motivasi Belajar Mahasiswa. Proximal Jurnal Penelitian Matematika Dan Pendidikan Matematika ISSN 26158132 (Cetak) ISSN 26157667 (Online), 2(1), 50-59. https://ejournal.my.id/proximal/article/view/211

Novalinda, E., Kantun, S., \& Widodo, J. (2018). Pengaruh Motivasi Belajar Terhadap Hasil Belajar Mata Pelajaran Akuntansi Siswa Kelas X Jurusan Akuntansi Semester Ganjil Smk Pgri 5 Jember Tahun Pelajaran 2016/2017. Jurnal Pendidikan Ekonomi: Jurnal Ilmiah Ilmu Pendidikan, Ilmu Ekonomi Dan Ilmu Sosial, 11(2), 115. https://doi.org/10.19184/jpe.v11i2.6456

Pratama, F., Firman, \& Neviyarni. (2019). Pengaruh Motivasi Belajar IPA Siswa Terhadap Hasil Belajar. EDUKATIF : Jurnal Ilmu Pendidikan, 1(3), 280-286. https://edukatif.org/index.php/edukatif/index\%0APENGARUH

Putri, G. K., \& Dewi, Y. A. S. (2019). Effect Of Google Classroom-Based Distance Learning Model. AlFikrah, 2(1), 60-79. 
1009 Efektivitas Penggunaan Google Classroom dan Motivasi Belajar Terhadap Hasil Belajar Peserta Didik Mata Pelajaran Ekonomi - Vivi Andyni Destyana, Jun Surjanti

DOI: https://doi.org/10.31004/edukatif.v3i3.507

Rahmanto, M. A., \& Bunyamin. (2020). Efektivitas Media Pembelajaran Daring Melalui Google Classroom. Jurnal Pendidikan Islam, 11(November), 119-135.

Sabran, \& Sabara, E. (2019). Keefektifan Google Classroom sebagai media pembelajaran. Prosiding Seminar Nasional Lembaga Penelitian Universitas Negeri Makasar, 122-125.

https://webcache.googleusercontent.com/search?q=cache:SS_jKM_r2TAJ:https://ojs.unm.ac.id/semnasl emlit/article/download/8256/4767+\&cd=2\&hl=id\&ct=clnk\&gl=id

Shaharanee, I. N. M., Jamil, J. M., \& Rodzi, A. S. S. M. (2016). The application of Google Classroom as a tool for teaching and learning. Journal of Telecommunication, Electronic and Computer Engineering, $8(10), 5-8$.

Stevani. (2016). Analisis Pengaruh Motivasi Belajar Terhadap Hasil Belajar Ekonomi Siswa Kelas X Sma Negeri 5 Padang. ECONOMICA : Journal Of Economic And Economic Education, 4(2), 308-314.

Suhada, I., Kurniati, T., Pramadi, A., \& Listiawati, M. (2020). Pembelajaran Daring Berbasis Google Classroom Mahasiswa Pendidikan Biologi Pada Masa Wabah Covid-19. Digital Library UIN Sunan Gunung Jati, 1-9. http://digilib.uinsgd.ac.id/30584/

Sukmawati. (2020). Implementasi Pemanfaatan Google Classroom Dalam Proses Pembelajaran Online di Era Industri 4 . 0. Jurnal Kreatif Online, 8(1), 39-46. http://jurnal.untad.ac.id/jurnal/index.php/JKTO/article/view/15680

Sulisworo, D., Agustin, S. P., Iii, K., \& Soepomo, J. P. (2017). Dampak Pembelajaran E-Learning Terhadap Motivasi Pada Pembelajaran Fisika Di Sekolah Kejuruan. Berkala Fisika Indonesia, 9(1), 1-7.

Sutrisno. (2020). Peningkatan aktivitas dan hasil belajar melalui pembelajaran online dengan google classroom di masa pandemi covid-19. Jurnal Karya Ilmiah Guru, 5(1), 95-106. https://jurnaldikpora.jogjaprov.go.id/index.php/jurnalideguru/article/view/151/162

Tanami Sukraini, T., Kasiani, \& Putu Yoga Laksana, I. (2020). Penerapan Google Classroom Terhadap Hasil Belajar pada Matakuliah Statistik Bisnis. Indonesian Society of Applied Science (ISAS), 6(2), 537-545.

Trisnaningsih, S., Suyanto, S., \& Rahayu, T. (2016). Pengembangan Learning Management System Quipper School pada Pembelajaran Materi Sistem Pertahanan Tubuh untuk Meningkatkan Motivasi dan Hasil Belajar Siswa Kelas XI di SMA Negeri 3 Yogyakarta. Jurnal Pendidikan Biologi, 5(6), 28-36.

Zubaidah, S. (2016). Keterampilan Abad Ke-21: Keterampilan Yang Diajarkan Melalui Pembelajaran. Seminar Nasional Pendidikan, 2, 1-17. 